\title{
PERAN MEDIA MASSA DALAM PENANGGULANGAN KEJAHATAN
}

\author{
Eka Nugraha Putra \\ Fakultas Hukum Universitas Merdeka Malang \\ Jl. Terusan Raya Dieng 62-64 Malang \\ eka.nugraha@unmer.ac.id
}

\begin{abstract}
In crime reduction policies, there are the penal and non-penal. Where the penal non preventative.Efforts to nonpenal could be shaped anything, the role of mass media in forming perception of crime and punishment is one.The mass media can do is through news the role of crime and have a partnership with law enforcement agencies. But there are still mass media that made the crime as a commodity course, while in conjunction with law enforcement agencies still limited to only as speakers course. The charge news in mass media particularly be caused by the violence can make the impact fear and not educate people. Writing that is the outcome of research these writers looked at how the role of media mass reduction policies evil, his involvement in law enforcement agencies and how strengthen the role of mass media in reduction policies evil. There are several problems in construction mass media will the news crime like the use of terminology, the news balanced and the judge. This closely related to construction mass media will news evil, that then will run according to on function preventive.Mass media in the context of policy penangggulangan evil may be also had a role in restore confidence the community and appreciation to law enforcement agencies, media a mass to be establish cooperation with law enforcement agencies. Do not have to a form of cooperation which are formil as long as can appreciate each other profession each and mutually beneficial. The role of media masses can also be implemented is all sides law enforcement agencies in construction news evil, until there is no law enforcement agencies whose performance be highlighted too big then cause a kind of competition with law enforcement agencies other.
\end{abstract}

Keyword: Mass Media, Criminal Policy, Non-Penal.

\begin{abstract}
ABSTRAK
Di dalam kebijakan penanggulangan kejahatan, terdapat upaya penal dan non-penal. Dimana upaya non penal bersifat preventif. Upaya non-penal ini bisa berbentuk apa saja, peranan media massa dalam membentuk persepsi atas kejahatan dan hukuman adalah salah satunya. Media massa dapat melakukan peranan ini melalui pemberitaan kejahatan dan melakukan kerjasama dengan lembaga penegak hukum. Namun masih ada media massa yang menjadikan berita kejahatan sebagai komoditas saja, sementara dalam hubungannya dengan lembaga penegak hukum masih sebatas sebagai narasumber saja. Muatan berita di media massa khususnya yang ada kaitan dengan berita kekerasan dapat menimbulkan dampak ketakutan dan tidak mengedukasi masyarakat. Tulisan yang merupakan hasil penelitian penulis ini mengkaji bagaimana peran media massa dalam kebijakan penanggulangan kejahatan, kerjasamanya dengan lembaga penegak hukum dan bagaimana memperkuat peranan media massa dalam kebijakan penanggulangan kejahatan. Terdapat beberapa permasalahan dalam konstruksi media massa akan pemberitaan kejahatan seperti penggunaan terminologi, pemberitaan yang berimbang dan pemberitaan yang menghakimi. Hal ini berkaitan erat dengan konstruksi media massa akan berita kejahatan, agar kemudian dapat berjalan sesuai pada fungsi preventif. Media massa dalam konteks kebijakan penangggulangan kejahatan dapat berperan juga dalam mengembalikan kepercayaan masyarakat dan apresiasi kepada lembaga penegak hukum, media massa dapat menjalin kerjasama dengan lembaga penegak hukum. Tidak harus merupakan kerjasama yang sifatnya formil asalkan dapat saling menghargai profesi masing-masing dan saling menguntungkan. Peran media massa ini juga bisa dilakukan dengan memenuhi semua sisi lembaga penegak hukum dalam konstruksi berita kejahatan, sehingga tidak ada lembaga penegak hukum yang kinerjanya disoroti terlalu besar lalu menimbulkan semacam persaingan dengan lembaga penegak hukum lainnya.
\end{abstract}

Kata Kunci: Kebijakan Penanggulangan Kejahatan, Media Massa, Non-Penal. 
Peran media massa dalam kebijakan penanggulangan kejahatan merupakan suatu strategi dalam penegakan hukum yang bertujuan untuk meminimalisir angka kejahatan dan mencapai ketertiban dalam masyarakat. Kebijakan penanggulangan kejahatan sendiri dapat berjalan dengan baik ketika kedua upaya di dalamnya, yaitu penal dan nonpenal dapat berjalan secara integral.

Upaya penal merupakan upaya melalui penegakan hukum pidana, sedangkan upaya non-penal sifatnya lebih ke arah kebijakan sosial, sehingga bisa berbentuk apa saja. Namun satu hal yang menarik, adalah bagaimana media massa juga dapat menjalankan peranan non-penal dalam penanggulangan kejahatan.

Namun pada masa sekarang ini, dengan kebebasan dan peran penting yang dimilikinya media massa sudah menjembatani hak masyarakat atas informasi dan membantu kinerja penegak hukum tentu harus dikaji lebih jauh. Karena dalam konteks kebijakan penanggulangan kejahatan atau politik kriminal media massa merupakan bentuk upaya preventif. Namun pada beberapa kasus pidana, khususnya kasus pidana yang besar dalam artian menyita perhatian publik cukup banyak, upaya preventif ini masih diragukan efektivitasnya, mengingat media massa tidak menunjukkan upaya atau fungsi preventifnya sebagai bagian dari kebijakan penanggulangan kejahatan, namun justru lewat proses jurnalistiknya menjadi seperti penyidik lewat "investigasi"-nya akan sumber berita, bahkan tak jarang pula proses pemberitaan media massa seolah mendahului pihak penegak hukum, khususnya kepolisian. Fenomena inilah yang menarik untuk dikaji, apakah posisi media saat ini sudah tepat dalam konteks kebijakan penanggulangan.

Pengkajian media massa terhadap peran dan kerjasamanya dengan sistem peradilan pidana Indonesia ini perlu agar media massa, di luar perannya sebagai sebuah media penyampai informasi juga bisa memberikan edukasi terhadap masyarakat sekaligus preventif dalam upaya non penal penanggulangan kejahatan.
Kurangnya kerjasama antara media massa dengan penegak hukum adalah hal yang ironis, apalagi ketika media massa lewat pemberitaannya tentang kasus-kasus kriminal justru menjadi penyebab kejahatan, bukan sebagai upaya preventif terhadap kejahatan di masyarakat.

Permasalahan dalam penelitian ini adalah terkait dengan peran media massa sebagai bagian kebijakan penanggulangan kejahatan sudah bekerja dalam fungsi preventifnya. Patut diketahui pula permasalahan yang menghambat sehingga dalam kebijakan penanggulangan kejahatan media massa belum mampu berperan efektif. Kerjasama media massa dan penegak hukum menjadi penting, sehingga penting pula mengkaji bentuk dukungan yang tepat dari media massa dalam kebijakan penanggulangan kejahatan agar ada sikap saling menghargai profesi dan hubungan yang saling menguntungkan dari kedua pihak dalam melakukan pekerjaannya tugas dan fungsinya.

\section{Metode Penelitian}

Untuk menjawab dan menganalisa permasalahan pada penelitian ini ini penulis menggunakan metode penelitian sosio-legal, Metode penelitian sosio-legal ini dipilih karena penulis melakukan pembahasan terhadap berjalannya kebijakan penanggulangan kejahatan lalu teori kriminologi dalam konteks pengaruh media massa sebagai faktor penyebab kejahatan dan upaya preventifnya dalam kebijakan penanggulangan kejahatan. Pendekatan yang digunakan adalah pendekatan kualitatif karena penulis menggunakan data primer berupa wawancara terstruktur kepada lembaga penegak hukum, pihak media massa dan praktisi media massa dan kriminologi. Penulis mengumpulkan informasi, merumuskan pertanyaan terkait lalu mengaitkan dengan teori dan asasasas yang ada.

Data primer menjadi unsur utama dalam penelitian ini maka penulis melakukan wawancara terstruktur dengan redaksi media cetak dan me- 
dia elektronik untuk mendalami cara penyajian berita media massa, bentuk kerjasama media massa dengan lembaga penegak hukum, selain itu wawancara terstruktur juga dilakukan dengan pihak Kepolisian, Kejaksaan dan Pengadilan untuk mendalami pandangan mereka tentang peran media massa dalam kebijakan penanggulangan kejahatan dan kerjasama lembaga penegak hukum tersebut dengan media massa. Untuk mendalami kajian teori sebagai pisau analisa dalam penelitian ini maka penulis juga melakukan wawancara terstruktur dengan praktisi komunikasi massa untuk mendalami etika pemberitaan yang benar oleh media massa, konstruksi media massa dalam pemberitaan kejahatan dan dampak media massa juga wawancara terstruktur dengan praktisi kriminologi untuk mendalami tentang newsmaking criminology dan dampak pemberitaan kejahatan dari media massa.

Penulis juga melakukan observasi pada artikel di media cetak dan internet serta beberapa tayangan di media televisi tentang kasus-kasus pidana, observasi ini bertujuan untuk mengamati konstruksi media massa terhadap pemberitaan kejahatan, maka pemberitaan yang akan diamati oleh penulis adalah yang berkaitan dengan hukum baik dalam bentuk kasus kejahatan jalanan maupun kejahatan besar seperti korupsi.

\section{Peran Media Massa di dalam Kebijakan Penanggulangan Kejahatan}

Media massa dalam setiap peristiwa membentuk konstruksi atas peristiwa tersebut untuk kemudian dijadikan sebagai sebuah sajian berita, pada konstruksi peristiwa menjadi berita inilah yang kemudian membedakan bentuk pemberitaan masing-masing media, karena tergantung atas tingkat kesadaran media terhadap etika jurnalistik (Wawancara Penulis dengan Prof. Ibnu Hamad).

Seperti yang disebutkan sebelumnya, bahwa media massa memiliki konstruksi tersendiri atas terjadinya sebuah peristiwa, sehingga konstruksi masing-masing media massa akan berbeda-beda. Dalam konstruksi media massa terhadap suatu fenomena kejahatan ada beberapa masalah yang dapat diuraikan sebagai berikut:

\section{Penggunaan Terminologi}

Penggunaan terminologi yang bermasalah di sini berarti penggunaan terminologi dalam redaksional suatu berita tentang kejahatan yang kurang pantas untuk dimuat atau juga penggunaan terminologi yang sebenarnya kurang tepat atau bahkan salah namun karena dimuat di media massa dan seringkali digunakan dalam pemberitaan, maka terminologi tersebut seolah menjadi benar. Penggunaan terminologi ini lazim ditemui pada media cetak, namun dapat juga ditemui juga media elektronik seperti televisi dalam narasi atau penggunaan judul dan lead berita yang ditayangkan. Mengenai penggunaan terminologi ini Iwan Awaludin Yusuf menguraikan cukup banyak kata yang seringkali digunakan dalam koran "Lampu Merah" yaitu "diinjek", "digebukin", "digamparin", "dipelintir", "digetok", "dialu", "dicekik" untuk berita kejahatan dengan unsur penganiayaan tanpa senjata tajam atau selain senjata tajam dan "dibacokin", "dibelah", "dibabat", "ditusuk", "dipisau", "digorok" untuk berita kejahatan yang mengandung unsur senjata tajam.

Ibnu Hamad berpendapat bahwa dalam penulisan berita kejahatan sebenarnya bisa disiasati dengan cukup menuliskan peristiwanya saja misalnya pembunuhan, sebaiknya dihindari penyebutan senjata dan luka yang dialami korban, Ibnu Hamad menambahkan selain masalah dampak pemberitaan kejahatan ini harus memperhatikan beberapa kepentingan yaitu pelaku, korban, keluarga korban, penegak hukum dan masyarakatnya.

Mengenai penggunaan terminologi ini Iqrak Sulhin menjelaskan contoh penggunaan statistik mengenai kejahatan, media massa seringkali menggunakan kata "signifikan" atau "konsisten" 
sebagai terminologi penjelas padahal dalam statistik sendiri kenaikan angka 10 dari 100 berbeda signifikansinya dengan kenaikan angka 100 dari 1.000.000 (Wawancara Penulis dengan Prof. Muhammad Mustofa) dalam hal statistik kejahatan, Muhammad Mustofa menambahkan contoh lain, bahwa media massa dalam menggunakan data bahwa ada kenaikan dalam statistik kejahatan pemerkosaan, padahal menurut Muhammad Mustofa, statistik kejahatan tidak hanya dinilai dari kenaikan angkanya saja, namun juga harus memperhatikan dan membandingkannya dengan kenaikan jumlah penduduk suatu daerah tersebut.

\section{Pemberitaan Berimbang}

Pemberitaan yang berimbang atau dalam istilah jurnalistik dikenal dengan cover both side memang mutlak diperlukan agar media massa dalam pemberitaannya proporsional dan tidak berat sebelah. Maka dalam konteks pemberitaan kejahatan pemberitaan yang berimbang seharusnya mengcover sisi pelaku, korban (atau keluarga korban), penegak hukum dan memperhatikan dampaknya terhadap masyarakat. Namun berdasarkan amatan penulis, berita-berita kejahatan yang ada cenderung menjadikan kejahatan tersebut sebagai sebuah komoditas, dengan dramatisasi baik dari redaksional yang dipilih maupun gambar-gambar yang ditayangkan.

Media massa cenderung menganggap cover both side sudah selesai diterapkan ketika dalam suatu kasus media massa meminta pendapat dari pihak A (korban atau tersangka atau pengacara) dan pihak B (penegak hukum). Padahal pemberitaan yang berimbang atau cover both side semestinya memperhatikan proporsi kutipan yang dimuat, berapa kalimat yang dikutip dan dimuat dari kedua belah pihak (Wawancara Penulis dengan Prof. Ibnu Hamad), atau dalam media televisi, penayangan wawancara kedua belah pihak harus diperhatikan agar mendapatkan proporsi durasi tayangan yang sama.
Pemberitaan berimbang dalam konteks pemberitaan kejahatan juga berarti pemberitaan yang proporsional terhadap bentuk-bentuk kejahatan. Seperti yang diungkapkan oleh Muhammad Mustofa, bahwa media massa cenderung menempatkan kejahatan-kejahatan jalanan (street crime) dengan porsi pemberitaan yang lebih besar dibandingkan kejahatan-kejahatan besar seperti kejahatan kerah putih (white collar crime) dan kejahatan terorganisir (organized crime), keduanya sama-sama merupakan kejahatan, namun sebenarnya kejahatan kerah putih dan kejahatan terorganisir memiliki bahaya yang lebih besar kepada masyarakat. Ketika media massa memberitakan tipe-tipe kejahatan yang kurang proporsional atau cenderung melebih-lebihkan suatu pemberitaan kejahatan, masyarakat akan menerima bahwa apa yang mereka dapat dari media massa merupakan realita yang ada di lapangan.

Konteks pemberitaan kejahatan yang ada sekarang, media massa memberitakan kejahatankejahatan besar seperti korupsi sekedar sebagai peringatan, bahkan pemberitaan korupsi semakin tinggi frekuensinya dengan pelaku yang berbedabeda, pada akhirnya pemberitaan seperti ini justru menjadikan media massa tidak bisa menjalankan fungsi preventifnya, karena tidak berlaku hanya menjadikan berita kejahatan sebagai sebuah komoditas saja.

\section{Pemberitaan yang Menghakimi}

Media massa memang memiliki kepentingan dalam memberikan informasi publik, apalagi setelah disahkannya Undang-Undang Nomor 14 Tahun 2008 Tentang Keterbukaan Informasi Publik, namun bukan berarti jaminan keterbukaan tersebut melupakan kepentingan penegakan hukum, kebebasan pers bukanlah kebebasan tanpa batasan dan tidak memperhatikan aturan yang berlaku. Sebagai contoh pemberitaan situs portal berita kompas.com tentang kasus dugaan korupsi pembahasan alokasi anggaran dana percepatan pembangunan infra- 
struktur daerah (DPPID) dimana salah satu kutipan beritanya dari pihak KPK hanya menyebutkan inisial tersangka namun kompas.com memberikan tanda kurung dan menyebutkan nama tersangkanya (www.kompas.com, 2011). Dalam konteks ini, Mardjono Reksodiputro berpendapat bahwa pemberitaan kejahatan seperti ini bisa merugikan pribadi seorang individu, apabila oleh pers melalui berita kejahatan, telah tersebar luas penangkapan seseorang yang disangka pelaku, namun dibebaskan kembali karena tidak ada atau kurang bukti atau bahkan memang tidak sama sekali tersangkut paut peristiwa tersebut (Mardjono Reksodiputro, 2010, 123).

Penulis sependapat dengan apa yang disampaikan Mardjono Reksodiputro terkait dengan trial by the public, media massa merupakan pihak yang menyuarakan masyarakat, maka apa yang disuarakan oleh media massa, dalam bentuk apapun kontennya seharusnya merupakan realitas atau opini masyarakat atas beragam realitas yang ada. Maka disinilah sebenarnya dibutuhkan pemahaman akan peraturan perundang-undangan dan juga etika pemberitaan, khususnya pemberitaan tentang kejahatan.

Pemberitaan kejahatan yang menggunakan inisial dan tidak memuat foto atau gambar dari orang yang diduga melakukan kejahatan (tersangka, terdakwa) merupakan bagian dari etika pemberitaan kejahatan tersebut, PWI sendiri sebagai salah satu organisasi profesi kewartawanan di Indonesia juga sudah mengeluarkan sepuluh pedoman pemberitaan tentang hukum yang intisarinya adalah sebagai berikut sebagaimana dikutip oleh Mardjono Reksodiputro $(2010,116)$ :

a. Agar menjunjung tinggi asas "praduga tak bersalah";

b. Agar menyebutkan secara lengkap nama tersangka atau terdakwa hanya dilakukan untuk kepentingan umum;

c. Agar jangan dimuat secara lengkap (jelas) identitas dari korban perkosaan atau dari para anak dan remaja yang tersangkut perkara pidana;

d. Agar anggota keluarga yang tidak ada sangkut pautnya dengan perkara, tidak ikut disebut dalam berita;

e. Agar dapat membantu "due process of law" melalui keterangan yang diperoleh dari luar persidangan;

f. Agar menghindari agar terjadinya "trial by the press";

g. Agar jangan menggunakan kata-kata sifat yang mengandung opini;

h. Agar memberi kesempatan seimbang kepada polisi, jaksa, hakim, pembela (tersangka/ terdakwa) dan petugas pemasyarakatan dalam pemberitaan opini;

i. Agar pemberitaan dilakukan secara proporsional, konsisten dan ada kelanjutan tentang penyelesaiannya;

j. Agar memberikan gambaran yang jelas mengenai duduknya perkara dan pihak-pihak dalam persidangan pengadilan.

Tri Agung Kristanto dari Harian Kompas menyatakan namun dalam konteks pihak yang menjadi tersangka atau terdakwa merupakan sosok yang diketahui umum, maka media massa akan memuat nama dan fotonya, Tri Agung Kristanto mencontohkan bahwa dalam kasus korupsi yang melibatkan terdakwa Akbar Tandjung misalnya, ketika dinyatakan bahwa tersangka adalah AT, Ketua DPR (pada saat kasus ini muncul) maka sebenarnya tidak perlu lagi dirahasiakan dalam bentuk inisial, justru ini merupakan bentuk kontrol (Wawancara Penulis dengan Kepala Desk Politik dan Hukum Harian Kompas, 2011).

Apabila pemuatan nama lengkap dan foto tersangka atau terdakwa dalam beberapa kasuskasus kejahatan besar memang dimaksudkan untuk bentuk kontrolnya terhadap berlangsungnya penegakan hukum, maka langkah ini sudah sesuai dengan kepentingan umum. Namun pemuatan 
nama dan foto tersangka dalam kasus-kasus kejahatan besar ini juga harus diikuti oleh pemuatan fakta-fakta yang benar dan tidak menyudutkan dalam bahasa pemberitaannya, artinya hak-hak individu walaupun sudah berstatus tersangka atau terdakwa tetap dilindungi, dalam hal kemudian tersangka atau terdakwa ini dibebaskan karena kurang bukti atau bahkan memang tidak bersalah, pemuatan berita terkait pembebasannya tersebut sudah merupakan bentuk rehabilitasi nama baik terhadap individu yang menjadi tersangka atau terdakwa tersebut (Wawancara Penulis dengan Kepala Desk Politik dan Hukum Harian Kompas, 2011).

Ketiga permasalahan dalam posisi media massa pada kebijakan penanggulangan kejahatan yang diuraikan di atas memiliki kaitan erat dengan bagaimana kemudian ketiga hal tersebut, memberikan dampak kepada opini publik yang baik terhadap penegakan hukum, kinerja penegak hukum atau kejahatannya sendiri. Konstruksi media massa dalam hal berita-berita kejahatan harus memperhatikan kepentingan segala pihak mulai dari pelaku sampai penegak hukum, maka dalam hal bagaimana media massa mengkonstruksi realita dan memberikan framing-nya dalam berita kejahatan maka kerja media massa tak semestinya tak hanya mengungkap fakta kejahatan yang ada dalam kasuskasus yang diberitakan, namun juga membangun opini yang tepat dan tidak menghakimi.

Konsep reciprocal determinism memberikan contoh dimana bisa saja seorang menjadi pelaku kriminal karena interaksi berkelanjutan dengan kognitif, perilaku dan lingkungan meskipun ia tinggal di lingkungan yang stabil secara ekonomi dan sosial. Pengaruh dari lingkungan ini termasuk dari media massa dimana konstruksi media massa terhadap peristiwa kejahatan atau kriminal dapat memberikan pengaruh.

Sebagaimana contoh dari penggunaan terminologi pada beberapa media massa dalam kasuskasus kejahatan jalanan di atas, hal ini bisa mem- berikan efek ketakutan, selain itu penggambaran kasus yang terlalu detail lewat narasi atau gambargambar yang memuat kekerasan, meskipun itu bukan kekerasan yang berasal dari kejahatan bisa memberikan pengaruh tingkat kejahatan. Penelitian yang dilakukan oleh David P. Phillips menunjukkan bahwa kekerasan yang ada di media massa memprovokasi perilaku agresif di dunia nyata. Melalui hipotesa "modelling", hasil penelitian ini menunjukkan kejuaraan tinju dapat memicu beberapa kasus pembunuhan melalui beberapa tipe peniruan kekerasan (David P. Phillips, 1983, 563). Sebagaimana pula diuraikan pada poin penggunaan terminologi di atas, konstruksi berita kejahatan pada media massa yang menggambarkan kejahatan, khususnya kejahatan kekerasan dengan terlalu detail akan dapat memberikan gambaran atau bahkan inspirasi kepada penonton untuk ditiru, sehingga kekhawatiran yang terburuk adalah hal itu ditiru dan kemudian peristiwa kejahatan yang sama terulang lagi.

Maka penting untuk media massa agar bekerja sesuai etika serta menjalankan fungsi preventif dan kontrolnya, hal ini berlaku baik dalam bentuk narasi atau gambar. Sehingga informasi yang sampai kepada masyarakat tidak memicu perilaku kekerasan, juga tidak menimbulkan opini publik yang salah.

Opini publik sendiri memang belum memiliki definisi yang disepakati sepenuhnya, namun menurut Anwar Arifin $(2010,12)$ ada beberapa makna dan pengertian dari opini publik yaitu:

a. Opini publik adalah pendapat, sikap, perasaan, ramalan pendirian dan harapan rata-rata individu kelompok dalam masyarakat, tentang sesuatu hal yang berhubungan dengan kepentingan umum atau persoalan-persoalan sosial;

b. Opini publik adalah hasil interaksi, diskusi atau penilaian sosial antar individu tersebut yang berdasarkan pertukaran pikiran yang sadar dan rasional yang dinyatakan baik lisan maupun tulisan; 
c. Isu atau masalah yang didiskusikan itu adalah hasil dari apa yang dioperkan oleh media massa (baik media cetak maupun elektronik);

d. Opini publik hanya dapat berkembang pada negara-negara yang menganut paham demokrasi. Dalam negara tersebut akan memberikan kebebasan kepada warganya untuk menyatakan pendapat dan sikapnya, baik lisan maupun tulisan.

Melihat dari makna dan pengertian yang diuraikan di atas, jelas bahwa media massa punya peranan penting dalam membangun opini publik. Opini publik ini kemudian akan melahirkan perwujudan tindakan-tindakan yang dilakukan oleh masyarakat yang bisa berupa partisipasi terhadap penegakan hukum sendiri, hal ini menunjukkan bahwa opini publik atau tindakan publik punya partisipasi yang penting dalam berjalannya sistem peradilan pidana (Julian V Roberts, 1992, 127).

Namun partisipasi publik dalam berjalannya sistem peradilan pidana ditegaskan oleh Julian V. Roberts bahwa akan muncul paradoks terkait sikap publik terhadap sistem peradilan pidana sendiri, kondisi ini terjadi menurut penelitian Julian V. Roberts ketika masyarakat semakin sadar tanggung jawab sistem peradilan pidana dalam mengontrol tingkat kejahatan, dimana angka kejahatan sendiri terus meningkat, lalu pada saat yang sama penegak hukum sebenarnya sudah melakukan pekerjaannya dengan baik (Julian V Roberts, 1992, 140). Paradoks tersebut akan ditemui dalam sikap publik yang kemudian justru memegang kendali berjalannya peradilan melebihi tanggung jawab dari penegak hukum sendiri dan ketika publik menyadari bahwa pengontrolan terhadap kejahatan bukan hanya masalah hukum pidana namun juga masalah sosial.

Permasalahan paradoks yang diungkapkan Julian V. Roberts di atas bila dikaitkan dengan bagaimana peran media massa membentuk opini publik lewat pemberitaan kejahatan, ketika per- masalahan paradoks yang diungkapkan tersebut muncul sampai pada tahap masyarakat mengendalikan peradilan melebihi tanggung jawab penegak hukum, maka ada pembentukan opini yang kurang tepat, atau bahkan menghakimi. Maka dalam pembentukan opini publik tersebut sebaiknya tidak dalam konteks menghakimi, framing memang ada dalam pemberitaan kejahatan oleh media massa, begitu pula kritik dan bentuk kontrol terhadap kinerja penegak hukum, namun tidak berarti apa yang disampaikan media massa kemudian membuat opini publik yang terbentuk adalah ketidakpercayaan masyarakat sendiri terhadap penegak hukum, meskipun kinerja penegak hukum memang memiliki kekurangan.

Pihak kepolisian mengungkapkan bahwa media massa yang memiliki prinsip "bad news is good news" membuat kinerja positif kepolisian sebagai penegak hukum jarang atau bahkan tidak diberitakan sama sekali. Menurut pihak kepolisian, ketika polisi menertibkan demonstrasi yang rusuh, media massa akan memberitakannya sebagai tindakan sewenang-wenang polisi, namun ketika polisi bekerja dalam pengaturan lalu lintas atau pelayanan publik lainnya media tidak memberitakannya (Wawancara Penulis dengan Humas Polda Metro Jaya, 2011). Media massa dalam hal apa yang disampaikan pihak kepolisian akan berpegang pada news value (nilai berita) dimana tindakan polisi untuk mengatur lalu lintas lebih sedikit news valuenya daripada penertiban demonstrasi yang rusuh, namun dalam konteks perannya dalam kebijakan penanggulangan kejahatan media massa sebenarnya harus memiliki porsi yang seimbang antara pemberitaan kekerasan dan pemberitaan perdamaian (Wawancara Penulis dengan Prof. Muhammad Mustofa, 2011).

Konstruksi media massa dalam pemberitaan kejahatan akan memberikan framing-nya dalam fungsi kontrolnya terhadap penegakan hukum, sebagaimana hasil wawancara penulis dengan media massa yang diuraikan sebelumnya. Namun konstruksi media massa dalam pemberitaan keja- 
hatan juga akan bermasalah ketika frekuensi dan substansinya meningkat, Steven Gorelick dalam studinya terhadap harian New York, sebagaimana dikutip oleh Vincent F. Sacco menguraikan bahwa kejahatan di kota tersebut dideskripsikan dalam frasa "mushrooming cloud", "floodtide" dan "spreading cancer" (Vincent F. Sacco, 1995, 147). Temuan Steven Gorelick ini menunjukkan bahwa media massa mengkonstruksi kejahatan dalam bentuk komoditas yang menakutkan bagi masyarakat, terlihat dari pemilihan deskripsi terhadap kejahatan tersebut.

Konteks media massa di Indonesia, hal ini juga dapat ditemui, selain permasalahan penggunaan statistik kejahatan seperti yang diuraikan sebelumnya, konstruksi media dalam pemberitaan kejahatan yang bisa menimbulkan ketakutan. Media massa mengakui bahwa pemberitaan kejahatan yang mereka lakukan dapat menimbulkan ketakutan, namun di sisi lain pemberitaan kejahatan ini dimaksudkan juga untuk menyampaikan kewaspadaan dan kecermatan akan tingkat kejahatan di lapangan (Wawancara Penulis dengan Kepala Desk Politik dan Hukum Harian Kompas).

Bentuk pemberitaan kejahatan dalam konstruksi kritik dan kontrol terhadap penegakan hukum seperti yang dilakukan Kompas sudah berada dalam koridor perannya sebagai bagian dari kebijakan penanggulanagan kejahatan, artinya Kompas sebagai salah satu contoh media massa tidak menghakimi namun mengungkap fakta dan memberikan edukasi. Permasalahannya adalah tentu tidak semua media massa memiliki langkah atau kinerja yang sama dalam memberitakan kejahatan. Media massa yang semestinya merupakan cerminan masyarakat masih ada yang terkait dengan kepentingan tertentu, sehingga tidak ada media yang benar-benar netral. Namun netral bukan berarti tidak mampu menjalin kerjasama dengan lembaga penegak hukum apabila berbicara kebijakan penanggulangan kejahatan.

\section{Bentuk Kerja Sama Antara Media dengan Penegak Hukum di dalam Kebijakan Penang- gulangan Kejahatan}

Di luar kerjasama media massa dengan penegak hukum dalam konteks pencari berita dan narasumber, tidak ada bentuk kerjasama secara riil antara media massa dengan penegak hukum. Pada sub bab ini pembahasan kerjasama media massa dengan penegak hukum akan dilakukan dengan menguraikan satu persatu temuan penulis di masingmasing lembaga penegak hukum:

\section{Kepolisian}

Penanggulangan kejahatan, atau lebih spesifik dalam proses penegakan hukum pidana, Kepolisian berperan dalam tahapan penangkapan, penahanan dan penyidikan tersangka sebelum dibawa ke Pengadilan. Proses-proses yang ditangani oleh Kepolisian ini tentu akan menarik perhatian masyarakat, apalagi bila menyangkut kasus-kasus besar seperti korupsi. Proses-proses yang ditangani oleh Kepolisian ini sifatnya merupakan tahapan pertama kali suatu kasus terungkap ke publik, khususnya nama tersangka dan sangkaan perbuatan yang dilakukan. Kasus-kasus yang biasanya cukup ramai diliput oleh media massa dan dicari informasinya dari pihak kepolisian biasanya adalah kasus korupsi atau kasus penganiayaan (Wawancara Penulis dengan Humas Polda Metro Jaya).

Upaya Kepolisian dalam menyampaikan informasi tentang suatu peristiwa kejahatan dibatasi hanya pada 3 unsur di atas karena memang proses pemeriksaan kasusnya baru berjalan dan belum dipastikan pelakunya bersalah, media massa dalam konteks mengawal kasus-kasus kejahatan sebagai bentuk kontrolnya terhadap penegakan hukum pidana berpendapat bahwa jumpa pers atau konferensi pers yang diadakan oleh pihak Kepolisian tidaklah cukup (Wawancara dengan Kepala Desk Politik dan Hukum Harian Kompas). Diakui oleh pihak media massa memang keterbukaan 
yang ada dari lembaga penegak hukum memang membantu, seperti mengadakan jumpa pers atau konferensi pers ini namun karena informasi yang diberikan biasanya umum, tentu dibutuhkan verifikasi oleh media massa dan penggalian informasi sebanyak-banyaknya tentang kasus kejahatan yang sedang ditangani tersebut.

Konstruksi berita kejahatan yang akurat dan tepat sasaran ini semestinya dapat memberikan efek takut, dalam artian menunjukkan ketegasan penegak hukum dalam penegakan hukum pidana, namun yang terjadi adalah konstruksi terhadap para penegak hukum menjadikan citranya kurang dapat dipercaya dan diapresiasi sehingga tidak ada ketakutan akan ketegasan hukum pidana yang dirasakan masyarakat.

Di luar kerjasama dalam bentuk memberikan informasi tentang kasus-kasus kejahatan yang sedang ditangani, pihak Kepolisian juga menyediakan balai wartawan yang digunakan oleh Kepolisian untuk melakukan pembinaan terhadap wartawan yang pos kerjanya di Kepolisian, selain itu juga ada PID, yaitu Pusat Informasi dan Dokumentasi yang berdiri di bawah Bidang Humas Polda Metro Jaya. Bidang Humas Polda Metro Jaya juga melakukan kunjungan-kunjungan ke beberapa redaksi media massa dalam rangka meningkatkan sosialisasi keterbukaan mereka terhadap publik dan juga meningkatkan hubungan baik antara Kepolisian sebagai penegak hukum dan media massa sebagai bagian dari masyarakat.

\section{Kejaksaan}

Apabila Kepolisian melakukan proses penegakan hukum pidana mulai dari proses penangkapan sampai Penuntutan, maka Kejaksaan bertindak dalam proses penyelidikan. Pada proses ini kasuskasus kejahatan yang ditangani tentu sudah memiliki perkembangan yang masif dan menarik untuk diikuti, bentuk kasus yang biasanya menarik perhatian media massa dalam peliputannya biasanya pada kasus-kasus yang terkait dengan pejabat, artis (publik figur), kasus kejahatan perbankan dan kasus-kasus yang memenuhi kualifikasi keempat seperti pencurian piring yang diproses pidana (Wawancara Penulis dengan Jaksa Kejaksaan Negeri Jakarta Selatan).

Tiap tingkat Kejaksaan, masing-masing memiliki bidang yang khusus menjadi bagian pelayanan informasi, salah satunya tentang penanganan kasus kejahatan yang sedang ditangani. Pada tingkat Kejaksaan Agung ditangani oleh Kapuspenkum (Kepala Pusat Penerangan Hukum), pada tingkat Kejaksaan Tinggi oleh Kasipenkum namun berbeda dengan di tingkat Kejaksaan Negeri, pelayanan ini ditangani langsung oleh Kasi masingmasing.

Kerjasama antara pihak Kejaksaan dengan media massa juga dilakukan dengan adanya koordinasi dalam bentuk Forwaka (Forum Wartawan Kejaksaan) dimana wartawan-wartawan yang tergabung di dalamnya memiliki akses yang lebih luas dalam pencarian informasi tentang kejahatan yang sedang ditangani.

\section{Pengadilan}

Tingkat pengadilan, setelah berkas lengkap maka kasus tersebut akan disidangkan untuk mencari kebenaran dan pada akhirnya menjatuhkan vonis pada terdakwa apakah dipidana atau bebas. Media massa banyak bekerja dan meliput pada proses ini, karena perkembangannya memiliki nilai berita yang menarik untuk diikuti.

Dasarnya persidangan di pengadilan memang terbuka untuk umum, kecuali pada sidang kasus kejahatan kesusilaan atau kejahatan yang berkaitan dengan anak-anak. Keterbukaan ini berarti selama persidangan media massa boleh masuk ke dalam ruang persidangan dan meliput jalannya persidangan. Secara teknis sendiri, dibutuhkan perijinan ketika media massa akan melakukan peliputan jalannya persidangan, termasuk mengambil gambar melalui kamera video atau foto (Wawancara 
Penulis dengan Hakim Pengadilan Negeri Jakarta Selatan). Namun berdasarkan hasil wawancara penulis, kesempatan mengambil gambar oleh media massa ini seringkali dilakukan pada waktu yang sebenarnya kurang tepat, sehingga sorot kamera atau blitz dapat menganggu jalannya persidangan (Wawancara Penulis dengan Hakim Pengadilan Negeri Jakarta Pusat).

Hampir sama dengan lembaga-lembaga penegak hukum lainnya, Pengadilan juga memiliki humas dalam rangka memberikan informasi tentang kasus yang sedang ditangani kepada masyarakat luas, khususnya media massa, namun seperti yang disampaikan pihak media massa Kompas yang diwawancara penulis, informasi dari bagian humas biasanya bersifat umum sehingga diperlukan verifikasi dan penggalian informasi lebih banyak oleh media massa. Penggalian informasi dan verifikasi ini juga bahkan dapat dilakukan dengan mewawancarai hakim yang menangani secara langsung, terhadap ini Hakim Lidya Sasando Parapat yang diwawancarai penulis menyatakan kurang setuju, karena pendapat hakim itu sifatnya tertutup.

Kerjasama antara media massa dengan lembaga penegak hukum, bahwa media massa dalam perannya di kebijakan penanggulangan kejahatan merupakan upaya non-penal, namun hal ini juga harus diiringi dengan kerjasama antara lembaga penegak hukum. Masalah yang sering ditemui adalah belum adanya koordinasi dan komunikasi antara komponen di dalam sistem peradilan pidana (Topo Santoso, 1999, 135). Apabila dikaitkan dengan konteks tulisan ini maka media massa semestinya bisa berperan juga dalam membangun kembali kerjasama antara lembaga penegak hukum, untuk kemudian kerjasama juga dijalin dari media massa dengan lembaga penegak hukum. Sebagaimana diuraikan Topo Santoso, permasalahan dalam sistem peradilan pidana salah satunya adalah adanya persaingan di antara mereka sendiri, misalnya persaingan antara jaksa dan hakim akan kekuasaan dan prestise yang lebih besar atau polisi yang tidak ingin menjadi "tangan kanan" jaksa dalam tugas penyidikan sebelum beralih pada jaksa untuk penuntutan, sebaliknya jaksa tidak ingin menjadi perantara perkara dari polisi ke pengadilan (Topo Santoso, 1999, 136).

Sudut pandang media massa sendiri, kerjasama media massa dengan lembaga penegak hukum bisa dilakukan dalam beberapa hal, seperti dalam hal gelar perkara, media massa dapat melakukan peliputan meskipun ini sifatnya cenderung informil (Wawancara Penulis dengan Produser Desk Hukum dan Kriminal TVOne, 2011). Kerjasama dalam bentuk lain menurut media massa contohnya bisa dilakukan dengan melakukan peliputan dari peristiwa di lapangan yang informasinya didapatkan dari TMC Polda Metro Jaya (Wawancara Penulis dengan Produser Desk Hukum dan Kriminal TVOne). Kerjasama dalam bentuk formil menurut penulis memang perlu dilakukan namun tentunya tidak boleh mengikat kinerja masing-masing baik media massa maupun lembaga penegak hukum, artinya media massa mendapatkan informasi secara cepat dan akurat dari lapangan tentang peristiwa hukum atau kasus kejahatan yang sedang ditangani dan lembaga penegak hukum mendapatkan kemudahan dalam sosialisasi pelayanan terhadap publik dan kontrol eksternal terhadap lembaga mereka sendiri.

Kerjasama formil ini penting, karena kehadiran Undang-Undang RI Nomor 14 Tahun 2008 Tentang Keterbukaan Informasi Publik yang pelaksanaannya belum sepenuhnya menjamin keterbukaan informasi publik. Hadirnya UndangUndang RI Nomor 14 Tahun 2008 Tentang Keterbukaan Informasi Publik diakui media massa memang menjadikan lembaga penegak hukum sedikit lebih baik dalam hal pengaruhnya akan kemudahan media massa untuk melakukan peliputan terhadap berita kejahatan meskipun pada pihak kepolisian menurut media massa masih ada keterikatan terhadap atasan atau pejabat yang lebih tinggi dalam hal memberikan informasi terbaru kepada 
media massa (Wawancara Penulis dengan Produser Desk Hukum dan Kriminal TVOne).

\section{Upaya Memperkuat Peran Media Massa dalam Mendukung Kebijakan Penanggulangan Kejahatan}

Media massa dalam konteks berita kejahatan memiliki Klasifikasi tersendiri mana berita kejahatan yang akan dimuat atau ditayangkan, karena tidak semua berita kejahatan akan diangkat dalam media massa. Peristiwa-peristiwa yang berkaitan dengan hukum atau kejahatan yang biasanya dimuat di media massa antara lain (L.R. Baskoro, 2010, 12-26):

a. Melibatkan tokoh atau orang terkenal

Sengketa hukum yang melibatkan tokoh atau orang yang terkenal di masyarakat, seperti pejabat pemerintahan, anggota DPR, artis atau tokoh masyarakat. Media melihat dalam posisi apakah tokoh ini bersalah atau tidak;

b. Berkaitan dengan skandal hukum Skandal hukum ini bisa terjadi pada individu atau pada suatu institusi baik swasta maupun pemerintahan. Pada persoalan ini media melihatnya dalam bentuk kontrol, bagaimana individu atau instansi yang dipercaya masyarakat ternyata terlibat skandal hukum;

c. Pertama kali terjadi

Persoalan hukum yang diangkat adalah ketika ada suatu kasus hukum yang baru pertama kali terjadi dan menarik perhatian publik. Media massa melihat dalam proses pertimbangan hakim terhadap kasus tersebut;

d. Memiliki problem hukum

Persoalan ini diangkat oleh media massa ketika ada suatu kasus hukum yang masih memunculkan perdebatan pro dan kontra atau dengan kata lain masih abu-abu. Media massa mengangkat persoalan ini dengan menampilkan silang pendapat tentang kasus tersebut agar masyarakat bisa mengambil kesimpulan terhadapnya; e. Proses pembuatan undang-undang

Media massa mengangkat persoalan ini dalam rangla menginformasikan sekaligus mengontrol proses pembuatannya, apakah ada kepentingan politik tertentu dan apakah undangundang ini dibuat oleh para wakil rakyat untuk kepentingan rakyat yang diwakilinya;

f. Melihat penerapan undang-undang baru Media massa melihat bagaimana penerapan undang-undang baru ini, apakah berjalan efektif atau tidak dan juga seberapa siap masyarakat atau para aparat hukum mengantisipasi berlakunya aturan baru ini;

g. Perselisihan antara lembaga hukum Dalam persoalan ini, media massa melihat dan mengangkat wewenang yang tumpang tindih atau juga perselisihan yang muncul menyangkut persoalan saling lempar tanggung jawab;

h. Pemilihan petinggi hukum

Media massa pada persoalan ini membeberkan dan ikut memberi penilaian, apakah seseorang cocok untuk mendapat dan menduduki jabatan-jabatan pada lembaga tinggi hukum tertentu;

i. Kisah-kisah pencari keadilan

Persoalan hukum ini cukup banyak terjadi dan pada beberapa kasus terjadi pada masyarakat yang miskin. Media massa mengangkat persoalan ini dalam bentuk feature, mengungkap suka dukanya sehingga dapat menggugah masyarakat sekaligus bentuk kritik kepada berjalannnya sistem hukum. Apabila masyarakat tergugah bisa jadi akan membantu para pencari keadilan ini;

j. Berkaitan dengan lembaga hukum atau aparat hukum

Dalam persoalan ini, media massa bisa mengangkat seputar profil dan tugas yang dikerjakan oleh lembaga atau aparat hukum yang bersangkutan dengan melihat dari sisi kemanusiaannya. 
Secara khusus pada poin (a) di atas, masih berkaitan dengan permasalahan yang telah diuraikan sebelumnya terkait pemberitaan berimbang, artinya media massa seharusnya dapat melihat tokoh ini bersalah atau tidak dengan cara melakukan konstruksi yang sama proporsinya dari semua yang terlibat, jangan sampai terjebak menjadi pihak yang memanaskan perbedaan di antara pihak-pihak yang terlibat. Sementara poin lainnya seperti proses pembuatan undang-undang dapat dikonstruksikan pada bagaimana perwakilan rakyat melakukan tugasnya dalam perancangan undang-undang, apakah ada pihak yang memiliki kepentingan atau tidak serius dalam tugasnya.

Peristiwa atau kasus hukum yang sering diangkat oleh media massa adalah kasus yang melibatkan sosok yang dikenal publik atau kasus yang memiliki dampak kepada publik (Wawancara Penulis dengan Produser Desk Hukum dan Kriminal TVOne), kasus yang memiliki dampak terhadap publik ini menurut media massa dinilai memiliki unsur sosial politis yang tinggi karena kemudian menjadi sebuah problem kebangsaan (Wawancara Penulis dengan Kepala Desk Politik dan Hukum Harian Kompas).

Sebagaimana diuraikan di atas, peliputan di persidangan banyak dilakukan media massa karena tahapan persidangan punya nilai berita yang cukup besar, khususnya dalam hal aktualitas. Namun dalam hal mengkonstruksi berita kejahatan atau berita mengenai peristiwa hukum pada tahapan persidangan media massa sebenarnya bisa memanfaatkan keberadaan pihak hakim, jaksa, pengacara, terdakwa, korban bahkan keluarga korban. Dilakukan agar media massa memperoleh informasi yang komprehensif untuk itu perlu untuk mengcover semua pihak dalam hal membangun konstruksi informasi berita yang berimbang dan objektif.

Persoalan-persoalan hukum tersebut memang memiliki nilai berita yang tinggi untuk dipublikasikan kepada masyarakat, namun melihat persoalan-persoalan hukum yang diangkat media massa tersebut, semuanya masih berada dalam koridor kontrol sosialnya, bukan preventif sebagaimana posisi semestinya media massa dalam kebijakan penanggulangan kejahatan. Fungsi kontrol sosial yang dijalankan media massa saat ini memang sudah tepat, namun kebijakan penanggulangan kejahatan membutuhkan keseimbangan, maka ketika dua bagian dalam kebijakan penanggulangan kejahatan sudah berada pada koridor represif yaitu aplikasi hukum pidana, maka media massa tentu juga harus memiliki upaya preventif dalam perannya sebagai bagian dari kebijakan penanggulangan kejahatan.

Beberapa media massa memang sudah menjalankan bentuk kontrolnya dengan baik, seperti yang dilakukan oleh Kompas, namun beberapa media massa masih menjadikan kejahatan sebagai bentuk komoditasnya semata, Satjipto Rahardjo menyebut media massa yang banyak memberitakan kejahatan kekerasan khususnya sebagai suatu institusi bisnis dari pada penjaga moral bangsa. Lebih lanjut menurut Satjipto Rahardjo bahwa dalam fungsi media massa sebagai pemberi informasi kepada masyarakat dan pembentuk opini publik tidak bisa disamakan dengan sosialisasi, yang artinya pemberitaan kejahatan yang dominan akan mendorong orang melakukan hal yang sama, namun pemberitaan kejahatan kekerasan yang sistematis dan ekspoitatif akan menciptakan keadaan stigmatik dalam diri bangsa.

Penulis merujuk pendapat Satjipto Rahardjo dengan melihat beberapa media massa yang lazim disebut dengan koran kuning, jenis media massa yang kontennya cenderung memberitakan kejahatan, apalagi kejahatan kekerasan secara berlebihan, khususnya dalam hal pemuatan foto pelaku, korban, judul yang bombastis dan penggunaan bahasa yang tidak etis. Bahwa media massa mengangkat suatu permasalahan di lapangan sebagai bentuk realita dan mengikuti apa yang diinginkan publik tentu hal tersebut memang merupakan bagian dari pekerjaan media massa, namun pe- 


\section{Peran Media Massa dalam Penanggulangan Kejahatan}

Eka Nugraha Putra

muatan berita kejahatan dengan berlebihan seperti yang dilakukan koran kuning tersebut tentu menimbulkan pertanyaan karena belum tentu itu merupakan apa yang dimau oleh masyarakat.

Maka dalam konteks pemberitaan kejahatan kekerasan yang dilakukan oleh beberapa media massa diperlukan penegakan aturan dan pemahaman etika yang lebih tegas, Abdul Mun'im Idries menjelaskan tanggung jawab sosial pers dalam meliput berita kejahatan yaitu (Pusat Antar Universitas Ilmu-Ilmu Sosial, Universitas Indonesia, 1991, 51):

a. Peliputan berita kejahatan, pers harus tetap berpedoman pada dua aspek, yaitu aspek idiil dan aspek komersial. Keduanya berkaitan satu dengan yang lainnya dan mutlak untuk menegakkan eksistensi pers, agar ia mampu melaksanakan fungsi sebagaimana mestinya. Hal tersebut hanya dapat terwujud bila para penyelenggara mampu mempertemukan secara harmonis atau menyelaraskan kedua aspek tersebut di dalam pelaksanaannya;

b. Menyajikan suatu informasi tidak diharapkan yang terlalu serius, dengan gaya yang memaksa pembaca selalu mengerutkan dahinya. Ia juga tidak hanya memusatkan diri pada upaya membentuk opini masyarakat. Pers dengan media massanya perlu pula memberikan suatu hiburan segar kepada para pembacanya, tanpa harus tergelincir dalam sensasi, yakni tulisantulisan yang baik isi maupun gaya penulisannya dapat merangsang atau membangkitkan emosi yang tidak sehat pada rata-rata pembacanya;

c. Selain memiliki integritas profesional yang tinggi, para wartawan diharapkan dapat meningkatkan kemampuan baik lewat pendidikan atau retraining, oleh karena hanya dengan demikian ia dapat melakukan fungsinya dengan baik. Meliput berita kejahatan yang menyangkut tubuh, kesehatan dan nyawa manusia kalangan pers diharapkan memiliki pengetahuan ilmu kedokteran forensik praktis agar dapat memberikan informasi yang baik dan benar.

Bahwa media massa belum sepenuhnya atau belum semuanya menjalankan tanggung jawab sosial ini. Pada poin menyeimbangkan aspek idiil dan komersial misalnya, masih nampak bahwa media massa cenderung pada sikap komersialnya. Hal ini memang tidak bisa dipungkiri karena media massa membutuhkan pendapatan agar bisa terus berjalan operasionalnya, namun bukan berarti kemudian mengabaikan kepentingan publik, sebagaimana penulis mengutip pendapat Muhammad Mustofa sebelumnya, bahwa media massa cenderung menjadikan peristiwa kejahatan sebagai sebuah komoditas dalam pemberitaannya.

Teori Newsmaking Criminology yang juga menjadi pisau analisa penulis untuk membahas posisi media massa dalam kebijakan penanggulangan kejahatan ini, salah satu faktor yang bisa menjadi penilaian adalah penggunaan kriminolog yang dengan pengetahuannya dapat menjadi sumber yang kredibel dalam formulasi kebijakan penanggulangan kejahatan dan kemudian dimediasi oleh media massa. Namun hal ini jarang sekali ditemui di Indonesia, memang media massa sering menggunakan pendapat pengamat atau pakar dalam pemberitaan kejahatan, namun masih sebatas pakar hukum pidana atau hukum lainnya, sementara pakar atau praktisi kriminologi jarang dijadikan narasumber padahal kriminolog kehadirannya dibutuhkan apabila pemberitaan kejahatan dari media massa bertujuan untuk mendidik masyarakat tentang keseriusan dari peristiwa kejahatan yang terjadi, selain itu juga ikut mempengaruhi kebijakan publik dalam mengendalikan kejahatan.

Beberapa media massa, khususnya televisi yang punya format acara bincang-bincang (talkshow) apabila temanya membahas suatu kejahatan ko- 
rupsi misalnya, penulis menemukan bahwa penggunaan narasumber justru hadir dari budayawan, pengamat komunikasi politik walaupun tetap menghadirkan pakar hukum. Hal ini memang tidak salah, apabila dimaksudkan untuk memberikan sudut pandang lain dari pemberitaan kejahatan atau memberitakannya dalam kerangka yang lebih ringan sehingga kemasannya tidak kaku, namun pemberitaan kejahatan tetap membutuhkan kerangka hukum dan kriminologi agar dapat memberikan informasi yang benar dan mengedukasi masyarakat.

Salah satu bentuk lain untuk memperkuat posisi media massa dalam kebijakan penanggulangan kejahatan adalah dengan merekonstruksi kembali kejahatan dan para penegak hukumnya, rekonstruksi ini tentu harus memperhatikan kepentingan korban, pelaku, keluarga korban, penegak hukum dan masyarakat. Cecil Greek sebagaimana dikutip oleh Iqrak Sulhin menjelaskan bahwa kajian Kriminologi Visual yang masih memiliki kaitan dengan Newsmaking Criminology yang merupakan suatu metode dalam penelitian Kriminologi, karena gambar (foto) dan rekaman audio visual (video) dapat dijadikan bahan analisis tentang realitas kejahatan dan sekaligus dapat digunakan untuk merekonstruksi gambaran atau citra tentang penjahat, kejahatan dan peradilan pidana agar lebih proporsional (Iqrak Shulhin, 2007, 9).

Contoh dari implementasi dari Kriminologi Visual ini dapat dilihat dalam street photography tentang interaksi polisi dengan masyarakat, dimana dapat difokuskan pada dua fenomena. Pertama, sistem peradilan pidana sebagai pekerjaan keseharian (polisi). Kedua, kondisi alamiah komunitas (masyarakat) dan situasi di mana polisi berinteraksi dengan warga masyarakat di jalanan dan di fasilitas peradilan pidana (Iqrak Shulhin, 2007, 10).

Mengingat kerjasama media massa dengan lembaga penegak hukum sebatas hubungan media dengan narasumber maka dibutuhkan kerjasama yang lebih intens, meskipun memang tidak akan mengikat agar masing-masing tetap independen namun agar bisa saling memahami kerja masing-masing. Salah satu permasalahan yang dikemukakan pihak Kepolisian adalah kedua pihak yakni media massa dan penegak hukum belum saling memahami urgensi pekerjaan masing-masing sehingga dalam melaksanakan pekerjannya belum tercipta hubungan yang saling menguntungkan, padahal jelas bahwa media massa membutuhkan berita sedangkan polisi sebagai salah satu penegak hukum membutuhkan media massa dalam rangka menginformasikan pelayanan mereka terhadap publik (Wawancara Penulis dengan Humas Polda Metro Jaya). Kerjasama ini tidak harus dalam bentuk tertulis seperti MOU (Memorandum Of Understanding) namun bisa dilakukan dengan memuatnya ke dalam kode etik profesi masing-masing agar bisa tetap menjaga independensi masing-masing.

\section{PENUTUP}

\section{Kesimpulan}

Berdasarkan hasil pembahasan di atas maka dapat disimpulkan bahwa dalam hal posisi media massa dalam kebijakan penanggulangan kejahatan saat ini baru berjalan pada fungsi kontrol saja. Dimana media massa melakukan konstruksi berita kejahatan dengan mengawal suatu peristiwa atau kasus kejahatan sejak pertama kali terjadi sampai pada perkembangan terakhirnya.

Fungsi kontrol ini sebenarnya tidaklah salah, namun dalam konteks kebijakan penanggulangan kejahatan, maka media massa seharusnya berjalan pada upaya non penal yang artinya berfungsi preventif terhadap terjadinya kejahatan, selain itu media massa belum banyak memberikan alternatif bersikap akan realitas kejahatan yang ada, karena kontennya banyak memberikan dampak ketakutan.

Kerjasama media massa dengan lembaga penegak hukum masih sebatas antara media pencari berita dengan narasumbernya saja, memang wajar mengingat kerjasama yang lebih jauh dapat me- 
mungkinkan adanya intervensi dari kedua belah pihak yang sama-sama menganggu. Namun hal ini di satu sisi menjadi masalah karena dalam konteks penanggulangan kejahatan tidak ada integrasi antara upaya penal dan non-penal. Kerjasama media massa dengan penegak hukum dapat membantu juga timbulnya kerjasama antar lembaga penegak hukum, karena masih ditemukannya persaingan antara lembaga penegak hukum dalam upaya penanggulangan kejahatan, maka peran media massa di sini adalah dalam rangka mengembalikan citra dan kepercayaan masyarakat yang sama di antara semua lembaga penegak hukum.

\section{Saran}

Upaya memperkuat peran media massa dalam kebijakan penanggulangan kejahatan tidak sebatas pada kontrol sosial terhadap penegakan hukum saja, namun juga harus diiringi pada bagaimana media massa dapat berjalan pada fungsi preventif, namun pada fungsi kontrol kepentingan hak asasi manusia yang terlibat di dalam suatu kasus kejahatan misalnya juga harus diperhatikan, maka mementingkan kepentingan publik akan keingintahuan terhadap informasi dengan kepentingan hak asasi manusia atas konstruksi pemberitaan yang proporsional juga harus diperhatikan, sehingga media massa tidak terjebak pada upaya menghakimi suatu peristiwa atau bahkan sosok yang terlibat di dalamnya.

\section{DAFTAR PUSTAKA}

\section{BUKU}

Adji, Indriyanto Seno, 2008, Hukum dan Kebebasan Pers, Diadit Media, Jakarta.

Adji, Oemar Seno, 1977, Mass Media dan Hukum, Erlangga, Jakarta.

Arief, Barda Nawawi, 2002, Bunga Rampai Kebijakan Hukum Pidana, PT. Citra Aditya Bakti, Bandung.
2008, Bunga Rampai Kebijakan Hukum Pidana, Kencana Prenada Media Grup, Jakarta.

Arifin, Anwar, 2010, Opini Publik, Gramata Publishing, Depok.

Arrigo, Bruce A, 2006, Criminal Behavior A Systems Approach, Pearson Prentice Hall, New Jersey.

Atmasasmita, Romli, 1996, Sistem Peradilan Pidana Perspektif Eksistensialisme dan Abolisionisme, Bina Cipta, Bandung.

Barkan, Steven E, 2006, Criminology A Sociological Understanding, Pearson Prentice Hall, New Jersey.

Baskoro, L.R., 2010, Jurnalisme Hukum Jurnalisme Tanpa Menghakimi, Jurnalis Indonesia dan Lintang Pers, Jakarta.

Hoefnagels, G. Peter, 1969, The Other Side Of Criminology, Deventer: Kluwer,

Jewkes, Yvonee, 2004, Media and Crime, Sage Publications, New Delhi.

Meliala, Adrianus. et.al., 2010, Bunga Rampai Kriminologi. dari Kejahatan dan Penyimpangan, Usaha Pengendalian sampai Renungan Teoritis, Departemen Kriminologi FISIP UI, Depok.

Muladi, 1995, Kapita Selekta Sistem Peradilan Pidana, Badan Penerbit Universitas Diponegoro, Semarang. 2002, Hak Asasi Manusia, Politik dan Sistem Peradilan Pidana, Badan Penerbit Universitas Diponegoro, Semarang.

dan Barda Nawawi Arief, 2010, Teori-Teori dan Kebijakan Pidana, Alumni. Bandung.

Prasetyo, Teguh, 2010, Kriminalisasi dalam Hukum Pidana, Nusa Media, Bandung.

Pusat Antar Universitas Ilmu-Ilmu Sosial Universitas Indonesia, 1991, Kriminalitas dalam Surat Kabar, Antar Kota, Jakarta.

Reksodiputro, Mardjono, 2007, Hak Asasi Manusia dalam Sistem Peradilan Pidana, Pusat Pelayanan dan Pengabdian Hukum Universitas Indonesia, Jakarta.

Rivers, William L., Jay W. Jensen dan Theodore Peterso, 2008, Media Massa dan Masyarakat Modern. 
Terjemahan Oleh Haris Munandar dan Dudy Priatna, Kencana Prenada Media Grup, Jakarta.

Sudarto, 1981, Kapita Selekta Hukum Pidana, Alumni, Bandung. 1977, Hukum dan Hukum Pidana. Bandung: Alumni.

Sunarso, Siswantoro, 2004, Penegakan Hukum dalam Kajian Sosiologis, Raja Grafindo Persada, Jakarta.

\section{JURNAL DAN KARYA ILMIAH}

Arief, Barda Nawawi, 1991, Upaya Non Penal Dalam Kebijakan Penanggulangan Kejahatan, Semarang: Makalah disampaikan dalam Seminar Kriminologi VI 16-18 September 1991.

Felson, Richard B, 1996, Mass Media Effects on Violent Behavior, Annual Review of Sociology, Vol. 22: Annual Review.

Ferrel, Jeff, 1999, Cultural Criminology, Annual Review of Sociology Vol. 25: Annual Review.

Phillips, David P., 1983, The Impact of Mass Media Violence on U.S. Homicides, American Sociological Association: American Sociological Review Vol. 48 No. 4 August 1983.

Rifai, Eddy, 1991, Peranan Media Massa dalam Penegakan Hukum Pidana (Suatu Studi Tentang Sarana Non Penal dalam Kebijakan Penanggulangan Kejahatan), Jakarta: Ini Fakultas Pasca Sarjana Universitas Indonesia.

Roberts, Julian V., 1992, Public Opinion, Crime and Criminal Justice, Chicago Journals Crime And Justice Volume 16. Chicago: University Of Chicago Press.

Sacco, Vincent F.,1995, Media Constructions Of Crime, Annals of the American Academy of Political and Social Science Vol. 539 May 1995: Sage Publications.

Santoso, Topo, 1999, Studi Tentang Hubungan Polisi dan Jaksa dalam Penyidikan Tindak Pidana pada Periode Sebelum dan Sesudah Berlakunya Kitab UndangUndang Hukum Acara Pidana, Jakarta: Ini Program Pasca Sarjana Fakultas Ilmu Hukum Universitas Indonesia.

Sulhin, Iqrak. News Making Criminology Sebuah Penafsiran Antara Kritik dan Aksi, Depok: Makalah Disam- paikan dalam Diskusi Internal Pusat Kajian Kriminologi. Departemen Kriminologi FISIP UI 28 Februari 2007.

\section{PERATURAN PERUNDANG-UNDANGAN}

Undang-Undang Republik Indonesia Nomor 21 Tahun 1982 Tentang Perubahan Atas Undang-Undang Nomor: 11 Tahun 1966 Tentang KetentuanKetentuan Pokok Pers Sebagaimana Telah Diubah Dengan Undang-Undang Nomor: 4 Tahun 1967 Lembaran Negara 52 Tambahan Lembaran Negara 3235.

Undang-Undang Republik Indonesia Nomor: 40 Tahun 1999 Tentang Pers Lembaran Negara 166 Tambahan Lembaran Negara 3887.

Undang-Undang Republik Indonesia Nomor: 32 Tahun 2002 Tentang Penyiaran Lembaran Negara 139 Tambahan Lembaran Negara 4252.

Undang-Undang Republik Indonesia Nomor: 14 Tahun 2008 Tentang Keterbukaan Informasi Publik Lembaran Negara 61 Tambahan Lembaran Negara 4846.

Kode Etik Jurnalistik.

\section{INTERNET}

Barak, Gregg. Doing Newsmaking Criminology from within the Academy. www.greggbarak.com. 2007.

Karuk, Mujiarto. Hubungan dengan Media. www.metro.polri.go.id. 2009.

RH, Priyambodo. Media Massa Gantikan Pemerintah Hadapi Korupsi. www.antaranews.com. 2010.

Tanpa Penulis. Pusat Penerangan Hukum. www.kejaksaan.go.id. 2009.

Tanpa Penulis. Newsmaking Criminology. www.kriminologi1.wordpress.com. 2009.

Tanpa Penulis. Struktur Organisasi Pengadilan. www.pnjakartapusat.go.id. Tanpa Tahun.

Yusuf, Iwan Awaludin. Menyoal Sensasi Berita Kriminal di Media. www.bincangmedia.wordpress.com. 2009. 


\section{Peran Media Massa dalam Penanggulangan Kejahatan}

Eka Nugraha Putra

Menonton Kematian? Nyalakan Televisi!. www.bincangmedia.wordpress.com. 2010.

\section{WAWANCARA}

Wawancara Penulis dengan Fikri Syaukani Produser Peliputan Desk Hukum dan Kriminal pada TVOne.

Wawancara Penulis dengan Hakim Lidya Sasando Parapat, SH, MH. dari Pengadilan Negeri Jakarta Pusat.

Wawancara Penulis dengan Hakim Usman, SH dari Pengadilan Negeri Jakarta Selatan.
Wawancara Penulis dengan Jaksa Dwi Astuti, SH. dari Kejaksaan Negeri Jakarta Pusat.

Wawancara Penulis dengan Jaksa Eri Yudianto, SH. dari Kejaksaan Negeri Jakarta Selatan.

Wawancara Penulis dengan Kompol Yulia, Divisi Humas Kepolisian Daerah Metro Jaya.

Wawancara Penulis dengan Prof. Ibnu Hamad Guru Besar Ilmu Komunikasi UI.

Wawancara Penulis dengan Prof. Muhammad Mustofa Guru Besar Kriminologi UI.

Wawancara Penulis dengan Tri Agung Kristanto, Kepala Desk Politik dan Hukum pada Harian Kompas. 